Reviews

\title{
Heavy Metals Complexed with Humic Substances in Fresh Water
}

\author{
Masataka HiRAIDE \\ Faculty of Engineering, Nagoya University, Nagoya 464-01, Japan
}

Chemical speciation has become an important and challenging area in the geochemical, toxicological and environmental fields. Metal-humic complexes are typical and important species because humic and fulvic acids dominate naturally occurring organic matter in fresh water. This article describes the separation and determination of metal-humic complexes, with information about physicochemical forms of the complexes. Typical preconcentration techniques for characterizing aquatic humic substances are also reviewed briefly,

Keywords Chemical speciation, heavy metals, humic acid, fulvic acid, macroreticular sorbents, water analysis

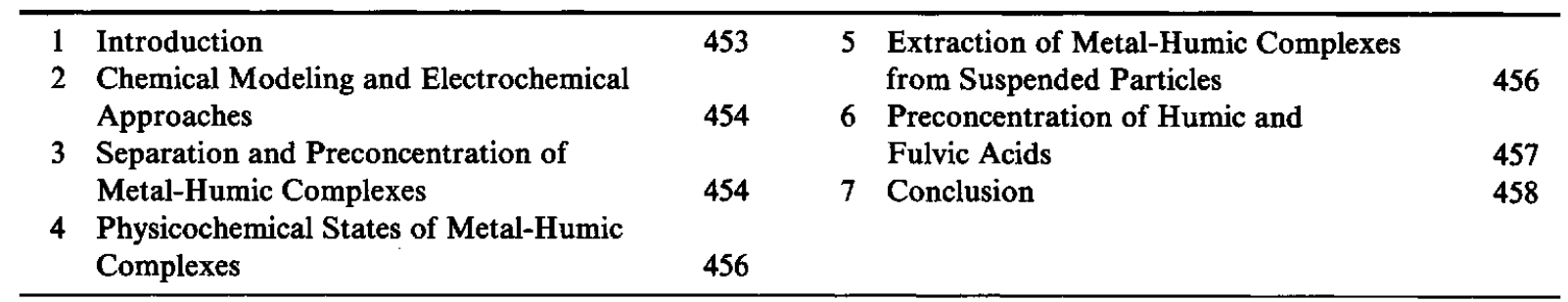

\section{Introduction}

Trace heavy metals exist in fresh water in various physicochemical forms, which include simple hydrated ions, hydroxo complexes, inorganic and organic complexes and colloidal particles. Heavy metals are also present in forms adsorbed on or occluded in heterogeneous colloidal and suspended particles. These chemical species often exhibit different geochemical behavior (interaction, transport and fate of metals) and biological effects (bioavailability, accumulation and toxicity). Chemical speciation, therefore, has been a topic of increasing research interest in geochemistry, biological sciences, environmental sciences and water treatment. ${ }^{1-5}$

Humic substances, the major and ubiquitous organic constituents of river, lake and pond water, derive from soils and sediments where they form through random reactions involved in chemical and microbial degradation of biological tissues. ${ }^{6,7}$ Humic substances are not well-defined compounds, but can generally be divided into three fractions: (1) humic acid, which is soluble in alkaline solutions, but precipitates in acid solutions; (2) fulvic acid, which is soluble in both alkaline and acid solutions; and (3) humin, which is insoluble in both solutions. Humic and fulvic acids can be described as acidic, hydrophilic, aromatic polymers containing carboxylic and phenolic hydroxyl groups. A suggested chemical structure for fulvic acid ${ }^{8}$ is shown in Fig. 1. The molecular weight of humic acid ranges from less than 700 to more than 2000000 , whereas fulvic acid fractions show a range of values from less than 700 to $10000 .^{9}$ Humic and fulvic acids are also known to interact with various metal ions, hydrated metal oxides, clay minerals and organic compounds. ${ }^{9-12}$

Metal-humic complexes, therefore, are expected to be the important and predominant species of heavy metals in fresh water. Relatively little information is available on the determination of the humic complexes, however. The measurement of complexing (or complexation) capacity ${ }^{3,11,13}$ is useful for estimating the ability of aquatic systems to render pollutant metals innocuous, but it is of little value in providing information on the concentration of metal-humic complexes.

This article attempts to provide a strategy for determining heavy metals complexed with humic and fulvic acids, paying particular attention to the selective and quantitative separation as well as the morphological characterization of submicron particles. The author also reviews some useful preconcentration techniques for collecting humic and fulvic acids from large volume samples. 


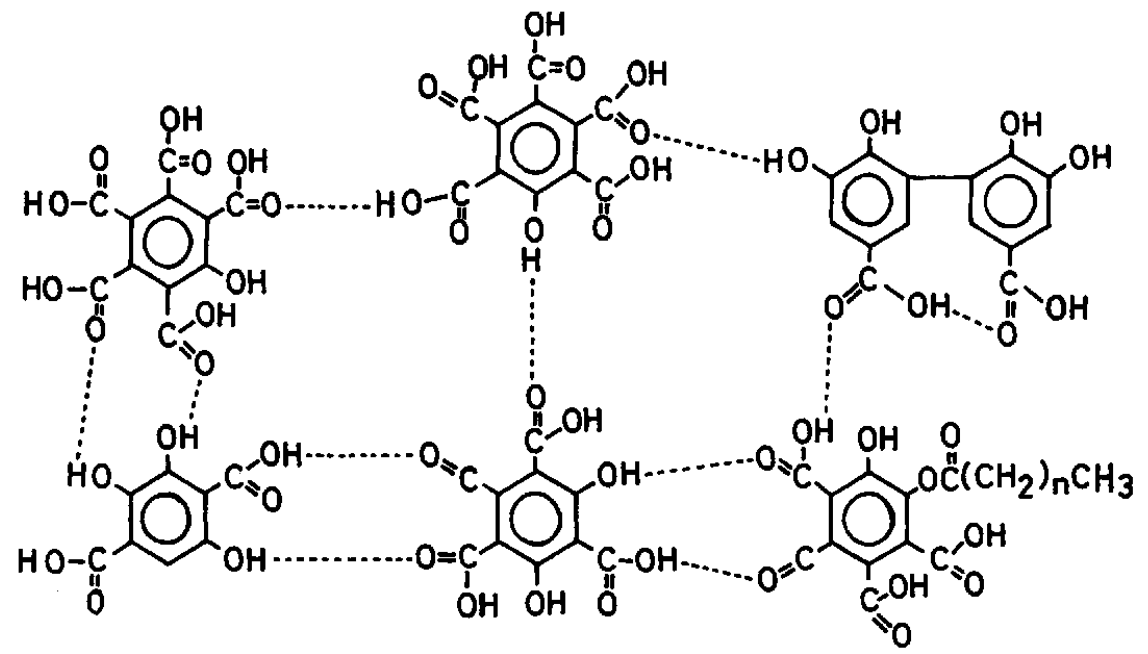

Fig. 1 A partial structure for fulvic acid. ${ }^{8}$

\section{Chemical Modeling and Electrochemical Approaches}

A tempting approach is chemical modeling, 3,14 , in which equilibrium concentrations of various chemical species are calculated with the aid of sophisticated computer programs. The applicability of the method, however, is rather restricted because of unreliable stability constants, inaccurate data for metal and ligand concentrations, and lack of information on heterogeneous interactions in the presence of colloidal and suspended particles.

Anodic stripping voltammetry (ASV) is capable of determining a number of heavy metals at extremely low concentrations. Speciation by ASV is based on labile / non-labile (inert) discrimination. ${ }^{4,15}$ The labile metal fraction includes free metal ions as well as metal ions dissociated from complexes or colloidal particles near the electrode. Given that the electrochemical lability of metal-humic complexes is low ${ }^{15,16}$, and that humic and fulvic acids are the predominant complexants in water, the ASV-inert fraction would correspond to metal-humic complexes.

Humic substances, however, gave rise to interference effects which changed the peak current, shape and potential, and biased the measurements of both the labile and non-labile fractions. ${ }^{17-20}$ Electrochemical lability of humic complexes was examined by graphite-furnace atomic absorption spectrometry (GFAAS) after sorption $^{21}$, where humic complexes were selectively sorbed on a diethylaminoethyl-Sephadex A-25 anion exchanger (see Section 3). The results suggested that nearly all lead-humic complexes and $50 \%$ of copper(II)-humic complexes behaved like ASV-labile species and could be determined as free metal ions.

Ion selective electrodes represent the only measurement technique responsive to free ion activity. They may be capable of indirect use to estimate metal-humic complexes, but the applicability to water analysis is severely limited because of poor sensitivity: the results are said to be unreliable below $10^{-6} \mathrm{M}$ concentrations for most elements. ${ }^{1,5}$

In general, therefore, separation and preconcentration steps are indispensable for the determination of metalhumic complexes in fresh water.

\section{Separation and Preconcentration of Metal- Humic Complexes}

Beneš et al. surveyed the interaction between 18 elements and humic substances in lake water. ${ }^{22}$ The speciation scheme consists of evaporation, ion exchange filtration, centrifugation and ultrafiltration, and hence analytical results seem to be so-called "operationallydefined" data which depend on experimental conditions. This work, however, is useful for understanding some general trends in metal-humic interactions.

A macroreticular styrene-divinylbenzene copolymer, Amberlite XAD-2 resin (surface area $313 \mathrm{~m}^{2} \mathrm{~g}^{-1}$, average pore diameter $9.1 \mathrm{~nm}$ ) sorbs organic species, via lowenergy physical interaction, depending on the aromaticity and size of the hydrophobic groups. ${ }^{23}$ Suzuki et al. used the XAD-2 resin for the collection of organic species (including humic complexes) in seawater. ${ }^{24,25}$ Mackey, however, reported that significant amounts of inorganic metal ions were also sorbed on the resin along with organic species. ${ }^{26,27}$ This phenomenon could be caused by polar impurities in the resin, i.e., by oxidized products having cation-exchange capacity (e.g., carboxyl groups). Methylation of the resin was not very effective for the elimination of the metal sorption..$^{27}$

This problem was successfully overcome by treating the XAD-2 resin with indium ions prior to the separation. ${ }^{28}$ The XAD-2 $(0.2-0.8 \mathrm{~mm}$ in diameter $)$ was pulverized to $1-10 \mu \mathrm{m}$ and washed ultrasonically in 
methanol, then in $2 \mathrm{M}$ nitric acid, followed by water. The resin was immersed in an indium solution $(10 \mu \mathrm{g}$ $\mathrm{ml}^{-1}, \mathrm{pH} \mathrm{5)}$ overnight to saturate the cation-exchange sites. Indium was selected for the following reasons: (1) trivalent indium ions are sorbed more strongly on the cation-exchange sites than bivalent and univalent ions; (2) indium does not interfere with GFAAS; (3) highpurity indium metal (e.g., 99.9999\% purity) is commercially available. The indium treatment was effective for eliminating the sorption of metal cations, as shown in Table 1, while the recovery of humic complexes was not disturbed at all. Metal anions such as chromium(VI), EDTA-complexes and colloidal hydrate metal oxides were not retained on the resin. The indium-treated XAD-2, however, may sorb organic species other than humic complexes, e.g., sodium dodecylbenzenesulfonate or sodium anthraquinonesulfonate. ${ }^{23}$ These compounds are not important because of the low complexing ability or negligible concentrations in unpolluted fresh water.

Another useful sorbent is a macroreticular anion exchanger, DEAE-Sephadex A-25 (Cl-form, crosslinked dextran gel with diethylaminoethyl groups) ${ }^{29}$, which is ultrasonically purified in $0.1 \mathrm{M}$ hydrochloric acid followed by water. Negatively charged humic complexes were quantitatively and rapidly sorbed on the A-25 column over a wide $\mathrm{pH}$ range, whereas metal cations and positively charged colloids were not retained at all. Anionic species such as metal-EDTA complexes were collectable, but this fraction was negligibly small for some metals (e.g., copper and lead) as described below.

Table 2 summarizes the analytical results for samples collected from local rivers. ${ }^{28,30}$ Humic complexes were sorbed on the indium-treated XAD-2 resin, while total amounts of negatively charged species (including humic

Table 1 Sorption of metal cations on the XAD-2 resin ${ }^{28}$

\begin{tabular}{|c|c|c|c|}
\hline Sorbent & \multicolumn{2}{|c|}{$\begin{array}{l}\text { Synthetic sample } \\
\text { containing } / \mu \mathrm{g} \mathrm{l}^{-1}\end{array}$} & $\begin{array}{l}\text { Metal sorbed } \\
\text { on the resin }{ }^{\mathrm{a}}, \%\end{array}$ \\
\hline \multirow{10}{*}{$\begin{array}{l}\text { Indium-treated } \\
\text { resin }\end{array}$} & \multirow{3}{*}{$\mathrm{Cu}(\mathrm{II})$} & 25 & 3 \\
\hline & & 30 & 4 \\
\hline & & 50 & 2 \\
\hline & $\mathrm{Pb}(\mathrm{II})$ & 25 & 4 \\
\hline & \multirow[t]{2}{*}{$\mathrm{Cd}(\mathrm{II})$} & 5.0 & 3 \\
\hline & & 10 & 8 \\
\hline & / $\mathrm{Cu}(\mathrm{II})$ & 50 & 6 \\
\hline & b $\mathrm{Pb}(\mathrm{II})$ & 50 & 5 \\
\hline & $\mathrm{Mn}(\mathrm{II})$ & 50 & 1 \\
\hline & $\mathrm{Cd}(\mathrm{II})$ & 10 & 1 \\
\hline \multirow{5}{*}{$\begin{array}{l}\text { Untreated } \\
\text { resin }\end{array}$} & $\mathrm{Cu}(\mathrm{II})$ & 30 & 63 \\
\hline & $\mathrm{Pb}(\mathrm{II})$ & 30 & 42 \\
\hline & $\mathrm{Cd}(\mathrm{II})$ & 5.0 & 16 \\
\hline & ${ }_{b}(\mathrm{Cu}(\mathrm{II})$ & 50 & 27 \\
\hline & $\mathrm{Pb}(\mathrm{II})$ & 50 & 26 \\
\hline
\end{tabular}

a. Obtained by analyzing the column effluent by GFAAS.

b. Simultaneously added. complexes) were collected on the A-25 anion exchanger. The sorbed metals were desorbed by ultrasonic irradiation in $4 \mathrm{M}$ nitric acid for the determination by GFAAS. Approximately $60-70 \%$ of dissolved copper and $20 \%$ of dissolved lead were present as humic complexes, which provided nearly all negatively charged fractions for those metals. About half of dissolved iron existed as humic complexes; significant amounts of iron $(25-35 \%)$ were found to be other negatively charged species (e.g., aggregates of hydrated iron(III) oxide, clay and hydrated silica). The humic fraction of cadmium was negligibly small, though weak interactions were reported for cadmium and humic substances. ${ }^{9}$

Tillekeratne $e t$ al. determined both fractions of humic complexes and metals associated with positively charged colloids. ${ }^{31}$ Humic complexes were sorbed on the A-25 column and desorbed with $4 \mathrm{M}$ nitric acid for GFAAS. Positively charged colloids remaining in the column effluent were collected on a $0.015-\mu \mathrm{m}$ Nuclepore membrane filter and ultrasonically dissolved in $1 \mathrm{M}$ nitric acid for the determination. The distribution of dissolved copper in river water was approximately: humic complexes $70 \%$, positively charged colloids $5 \%$, and cations $25 \%$.

Since rather strong interaction was reported for chromium(III) and humic substances ${ }^{32}$, sorption on the A-25 was applied to the differentiation of chromium(III)humic complexes, chromium(III) cations and chro-

Table 2 Determination of humic complexes in river water ${ }^{28,30}$ $\left(\mu \mathrm{g} \mathrm{l}^{-1}\right)$

\begin{tabular}{cccc}
\hline $\begin{array}{c}\text { Filtered } \\
\text { sample }^{\mathrm{a}-\mathrm{c}}\end{array}$ & $\begin{array}{c}\text { Humic } \\
\text { complexes }\end{array}$ & $\begin{array}{c}\text { Negatively } \\
\text { charged }^{\text {species }}{ }^{\mathrm{d}}\end{array}$ & $\begin{array}{c}\text { Total } \\
\text { dissolved } \\
\text { species }\end{array}$ \\
\hline $\begin{array}{c}\text { Shonai river } \\
\text { No. 1 Cu }\end{array}$ & 0.9 & 1.0 & \\
$\mathrm{~Pb}$ & 0.2 & 0.3 & 1.5 \\
$\mathrm{Cd}$ & 0.02 & 0.04 & 0.7 \\
No. 2 Cu & 1.4 & 1.5 & 0.11 \\
$\mathrm{Fe}$ & 15 & 21 & 1.9 \\
No. 3 $\mathrm{Cu}$ & 1.3 & 1.5 & 26 \\
$\mathrm{Fe}$ & 24 & 37 & 46 \\
Kiso river & & & \\
No. 1 Cu & 1.0 & 1.1 & 1.5 \\
$\mathrm{~Pb}$ & 0.2 & 0.3 & 1.2 \\
$\mathrm{Cd}$ & 0.01 & 0.01 & 0.09 \\
No. 2 Cu & 0.8 & 0.9 & 1.4 \\
$\mathrm{Fe}$ & 31 & 48 & 50 \\
Tempaku river & & & \\
No. 1 Cu & 1.6 & 1.8 & 2.2 \\
Fe & 84 & 126 & 138 \\
\hline
\end{tabular}

a. Sampled on separate days.

b. Suspended particles removed by filtration: $4-9 \mathrm{mg}^{-1}$.

c. Concentration of humic substances: $0.3-0.5 \mathrm{mg} \mathrm{l}^{-1}$ (determined by spectrophotometry).

d. Including humic complexes. 
mium(VI) anions. ${ }^{33}$ Negatively charged humic complexes and chromium(VI) were quantitatively sorbed on the A-25 column, leaving chromium(III) cations in the solution. The column was treated with $5 \%(\mathrm{w} / \mathrm{v})$ hydroxylammonium chloride solution ( $\mathrm{pH} 3$ ) to remove the chromium(VI) by reduction. The chromium(III)humic complexes were then desorbed with $4 \mathrm{M}$ nitric acid for the determination by GFAAS. In river water, chromium(VI) was dominant and humic complexes were less than $10 \%$ of total dissolved chromium.

Other applications of the A-25 sorption include the evaluation of formation and dissociation of copper(II)humic complexes. Taga et al. estimated conditional stability constants by the A-25 and Scatchard plot method. ${ }^{34}$ The results indicated that humic acid had many binding sites with different stability constants. Dissociation of copper(II)-humic complexes ${ }^{35}$ was studied from the standpoint that acidification of fresh water, originating mainly from sulfur and nitrogen oxides in the atmosphere, may cause the decomposition of humic complexes to release toxic copper(II) ions. Hydrochloric, sulfuric and nitric acids exhibited a similar effect on the dissociation, in which the humic complexes were not sensitive to an increase in acidity down to $\mathrm{pH} 4$.

\section{Physicochemical States of Metal-Humic Complexes}

Physicochemical forms of humic complexes were examined for copper and iron. ${ }^{36}$ Table 3 shows the results for humic complexes fractionated according to the particle sizes. Nuclepore polycarbonate etchedtrack membrane filters were used for the size fractionation because they have individual channels of uniform diameter. ${ }^{37}$ Copper-humic complexes were nearly completely passed through a $0.015-\mu \mathrm{m}$ filter, suggesting that they were not associated with colloidal particles (e.g., with hydrated metal oxides, clay particles or their mixtures). By contrast, most iron-humic species were retained on the filter, indicating that they were colloidal particles.

Humic colloids of iron may consist of hydrated iron(III) oxide, clay particles and humic substances. . $^{30,36}$ This is supported by the morphological study ${ }^{38}$ of submicron particles with a high-resolution transmission electron microscope and an energy dispersive X-ray analyzer. Figure 2 shows the elemental compositions of individual particles in pond and river water. Most particles contained iron, aluminum and silicon, with the aluminum-silicon weight ratio of about 1:1. The results suggest that most particles are aggregates of hydrated iron(III) oxide and aluminosilicate particles like kaolin clay. In addition, these particles strongly sorb humic and fulvic acids. ${ }^{39}$

\section{Extraction of Metal-Humic Complexes from Suspended Particles}

On the basis of the extraction of humic substances from sediments and soils ${ }^{8,40}$, a microscale separation technique was developed to extract humic complexes from small amounts of suspended particles. ${ }^{39}$ Milligram quantities of suspended particles were collected by centrifugation and humic complexes were manually extracted into $0.7 \mathrm{ml}$ of $0.1 \mathrm{M}$ sodium hydroxide solution. After centrifugation, the supernatant solution was analyzed for copper and lead by GFAAS. Morphological study and elemental analysis indicated that suspended particles were very similar to submicron particles (aggregates of hydrated iron(III) oxide and

Table 3 Size fractionation of humic complexes in river water ${ }^{36}\left(\mu \mathrm{g} \mathrm{l}^{-1}\right)$

\begin{tabular}{|c|c|c|c|c|c|c|}
\hline \multicolumn{3}{|c|}{ Sample } & \multirow{2}{*}{$\frac{\text { Particle size } / \mu \mathrm{m}}{1-0.015}$} & \multirow{2}{*}{$\frac{\text { Humic complexes }}{0.1}$} & \multirow{2}{*}{$\begin{array}{c}\begin{array}{c}\text { Negatively charged } \\
\text { species }^{b}\end{array} \\
0.2\end{array}$} & \multirow{2}{*}{$\begin{array}{c}\begin{array}{c}\text { Total dissolved } \\
\text { species }\end{array} \\
-^{c}\end{array}$} \\
\hline Shonai river & No. 1 & $\mathrm{Cu}$ & & & & \\
\hline & & & $<0.015$ & 0.9 & 0.9 & 1.5 \\
\hline & & $\mathrm{Fe}$ & $1-0.015$ & 51 & 77 & 85 \\
\hline & & & $<0.015$ & 1 & 3 & 5 \\
\hline & No. 2 & $\mathrm{Cu}$ & $1-0.1$ & 0.1 & 0 & 0.1 \\
\hline & & & $<0.1$ & 1.2 & 1.4 & 2.3 \\
\hline & & $\mathrm{Fe}$ & $1-0.1$ & - & 76 & 91 \\
\hline & & & $<0.1$ & - $^{c}$ & 9 & 9 \\
\hline \multirow[t]{8}{*}{ Kiso river } & No. 1 & $\mathrm{Cu}$ & $1-0.015$ & 0 & 0.1 & 0.1 \\
\hline & & & $<0.015$ & 0.5 & 0.5 & 0.7 \\
\hline & & $\mathrm{Fe}$ & $1-0.015$ & 27 & 46 & 51 \\
\hline & & & $<0.015$ & 4 & 6 & 7 \\
\hline & No. 2 & $\mathrm{Cu}$ & $1-0.1$ & _- $^{c}$ & 0.1 & 0.2 \\
\hline & & & $<0.1$ & $-^{c}$ & 0.7 & 0.9 \\
\hline & & $\mathrm{Fe}$ & $1-0.1$ & $-^{c}$ & 25 & 28 \\
\hline & & & $<0.1$ & $-^{\mathrm{c}}$ & 7 & 8 \\
\hline
\end{tabular}

a. Sampled on separate days. b. Including humic complexes. c. Not determined. 
clay).

Table 4 shows the sorption and desorption behavior of humic substances, heavy metals and their complexes. Almost all of them were sorbed on artificially prepared particles (kaolin covered with hydrated iron(III) oxide), and humic complexes were quantitatively and selectively desorbed with $0.1 \mathrm{M}$ sodium hydroxide solution.

Table 5 summarizes the results for river water samples. Phytoplankton was abundantly found in the sample, but

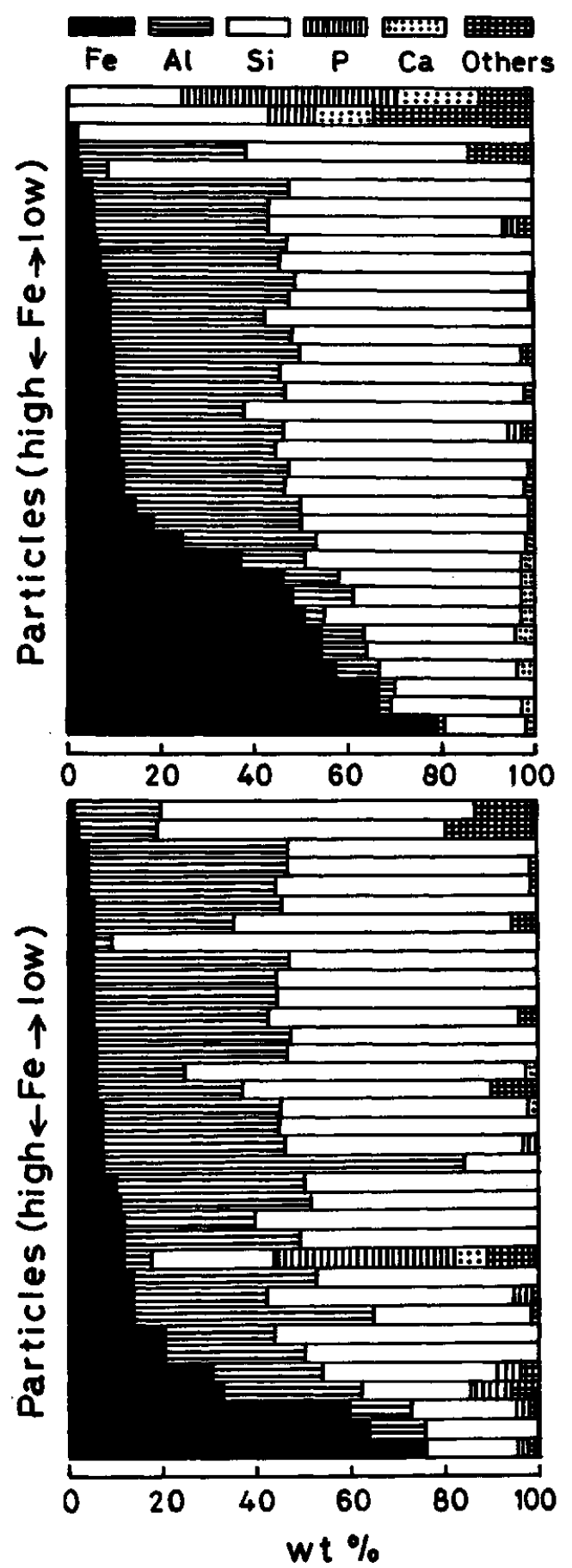

Fig. 2 Elemental compositions of submicron particles in pond (top) and river water (bottom). ${ }^{38}$ only negligibly small amounts of copper and lead were released into the extractant. Approximately $60 \%$ of copper and $30 \%$ of lead on or in suspended particles were present in the form of humic complexes.

\section{Preconcentration of Humic and Fulvic Acids}

It is beyond the scope of this paper to deal with the characterization methods of humic substances (e.g., for size distributions, functional groups, elemental compositions, absorption spectra, fluorescence phenomena and oxidation degradation). However, some useful preconcentration techniques for the recovery of aquatic humic substances are worth stressing here because appreciable amounts are required to characterize them and to study the correlation of aquatic and terrestrial humic substances.

Table 4 Extraction of humic complexes from artificially prepared suspended particles ${ }^{39}(\mu \mathrm{g})$

\begin{tabular}{lclcc}
\hline \multicolumn{2}{c}{$\begin{array}{c}\text { Sample solution, 20 ml, } \\
\text { containing }\end{array}$} & & $\begin{array}{c}\text { Sorbed on } \\
\text { particles }^{\mathrm{b}}\end{array}$ & $\begin{array}{c}\text { Desorbed with } \\
0.1 \mathrm{M} \mathrm{NaOH}\end{array}$ \\
\hline $\mathrm{Cu}$ & 0.50 & $(0.20)$ & 0.46 & 0.20 \\
$\mathrm{~Pb}$ & 0.50 & $(0.16)$ & 0.50 & 0.14 \\
$\mathrm{Humic}$ acid $^{\mathrm{c}}$ & 50 & & 48 & 46 \\
$\mathrm{Cu}$ & 0.50 & $(0.26)$ & 0.46 & 0.22 \\
$\mathrm{~Pb}$ & 0.50 & $(0.16)$ & 0.46 & 0.12 \\
$\mathrm{Humic}$ acid $^{\mathrm{c}}$ & 50 & & 50 & 48 \\
$\mathrm{Cu}$ & 0.50 & $(0.24)$ & 0.46 & 0.22 \\
$\mathrm{~Pb}$ & 0.50 & $(0.22)$ & 0.50 & 0.26 \\
Fulvic acid $^{d}$ & 100 & & 96 & 108 \\
\hline
\end{tabular}

a. Metals complexed with humic substances in parentheses.

b. Kaolin, $5 \mathrm{mg}$, covered with hydrated iron(III) oxide.

c. Extracted from peat soil.

d. Extracted from volcanic ash soil.

Table 5 Analysis of river water ${ }^{39}\left(\mu \mathrm{g} \mathrm{l}^{-1}\right)$

\begin{tabular}{|c|c|c|c|c|}
\hline \multirow{2}{*}{ Sample $^{\mathbf{a}}$} & & \multicolumn{2}{|c|}{ Suspended particles ${ }^{b}$} & \multirow{2}{*}{$\begin{array}{c}\text { Total } \\
\text { dissolved } \\
\text { species }\end{array}$} \\
\hline & & Humic complexes & Total $^{c}$ & \\
\hline \multicolumn{5}{|l|}{$\begin{array}{l}\text { Shonai river } \\
\qquad\left(4.4 \mathrm{mg} \mathrm{l}^{-1}\right)\end{array}$} \\
\hline & $\mathrm{Cu}$ & 0.28 & 0.50 & 1.2 \\
\hline & $\mathrm{Pb}$ & 0.05 & 0.19 & 0.8 \\
\hline \multicolumn{5}{|c|}{$\begin{array}{l}\text { Tempaku river } \\
\left(7.2 \mathrm{mg} \mathrm{l}^{-1}\right)\end{array}$} \\
\hline & $\mathrm{Cu}$ & 0.71 & 1.15 & 1.7 \\
\hline & $\mathrm{Pb}$ & 0.07 & 0.24 & 0.6 \\
\hline
\end{tabular}

a. Concentration of suspended particles in parentheses.

b. Humic and fulvic acids in $1 \mathrm{mg}$ of suspended particles:

$14 \mu \mathrm{g}$ (Shonai river) and $18 \mu \mathrm{g}$ (Tempaku river).

c. After decomposition with perchloric, nitric and hydrofluoric acids. 
The most commonly used technique is sorption on macroporous Amberlite XAD resins ${ }^{6,41}$, though a macroreticular anion exchanger, diethylaminoethyl (DEAE)-cellulose ${ }^{42,43}$, is also useful. Among the XAD series, the styrene-divinylbenzene copolymer XAD-244,45 and methacrylate-based copolymer XAD- ${ }^{46-48}$ have been most frequently used for the collection of humic and fulvic acids. The sorption is generally achieved from slightly acidic solutions (e.g., at $\mathrm{pH} 1-2$ ). The humic substances are then desorbed from the resins with alkaline solutions or their mixtures with water-miscible organic solvents.

A coprecipitation-flotation technique was applied to the recovery of humic acid at $\mu \mathrm{g}^{-1}$ levels from river water. 49,50 Humic acid in 11 of sample was quantitatively coprecipitated with small amounts of hydrated iron(III) oxide (10 $\mathrm{mg}$ as $\mathrm{Fe}$ ) at $\mathrm{pH} 7$, leaving fulvic acid in the solution. The precipitate was separated from the mother liquor by flotation with anionic surfactants (sodium oleate plus sodium dodecyl sulfate) and nitrogen bubbles, and then dissolved in $2 \mathrm{M}$ hydrochloric acid. The acid-insoluble humic acid was collected on a polysulfone ultrafilter (molecular weight cutoff 10000) and dissolved in $0.1 \mathrm{M}$ potassium hydroxide solution. The humic solution was used for measurements of absorption spectra, molecular weight distribution and complexing ability.

The procedure of coprecipitation and flotation in a flow system ${ }^{51}$ was highly effective to treat large volume samples (e.g., more than 100 1). In a stream of water, humic substances were coprecipitated with hydrated indium oxide and immediately floated on the solution surface. This continuous technique was more rapid and easier in operation than conventional coprecipitation techniques.

\section{Conclusion}

Generally, the direct determination of individual chemical species is very difficult because of extremely low concentrations and complexing characteristics of natural water systems. Advances in separation techniques, however, have led to the realization that metal-humic complexes predominate among the forms of some trace heavy metals in fresh water. The chemical and morphological characterization of submicron particles has revealed the large differences in physicochemical states between copper- and iron-humic complexes. The study required in the future includes a comprehensive survey of humic fractions for all heavy metals as well as elucidation of formation and dissociation behavior of humic complexes, which is essential for a better understanding of the environmental and geochemical role of metal-humic complexes.

The author would like to acknowledge Prof. Dr. Hiroshi Kawaguchi of Nagoya University for valued comments and discussions.

\section{References}

1. T. M. Florence, Talanta, 29, 345 (1982).

2. H. W. Nürnberg, Fresenius' Z. Anal. Chem., 316, 557 (1983).

3. G. G. Leppard (ed.), "Trace Element Speciation in Surface Waters and Its Ecological Implications", Plenum Press, New York, 1983.

4. D. T. E. Hunt and A. L. Wilson, "The Chemical Analysis of Water: General Principles and Techniques", 2nd ed., p. 559, The Royal Society of Chemistry, London, 1986.

5. G. E. Batley (ed.), "Trace Element Speciation: Analytical Methods and Problems", CRC Press, Boca Raton, 1989.

6. R. F. Christman and E. T. Gjessing (eds.), "Aquatic and Terrestrial Humic Materials", Ann Arbor Science Publishers, Michigan, 1983.

7. K. Kumada, "Dojou Yuukibutsu no Kagaku (Chemistry of Organic Matter in Soils, in Japanese)", 2nd ed., Gakkai Shuppan, Tokyo, 1981.

8. M. Schnitzer and S. U. Khan (eds.), "Soil Organic Matter", Elsevier, Amsterdam, 1978.

9. S. Boggs, D. G. Livermore and M. G. Seitz, J. Macromol. Sci-Rev. Macromol. Chem. Phys., C25, 599 (1985).

10. H. Kerndorff and M. Schnitzer, Geochim. Cosmochim. Acta, 44, 1701 (1980).

11. J. Buffle, "Complexation Reactions in Aquatic Systems: An Analytical Approach", Ellis Horwood Ltd., Chichester, 1988.

12. "Humic and Fulvic Compounds", Anal. Chim. Acta, 232, No. 1 (Special issue), (1990).

13. W. Salomons and U. Forstner, "Metals in the Hydrocycle", Springer-Verlag, Berlin, 1984.

14. T. M. Florence and G. E. Batley, CRC Crit. Rev. Anal. Chem., 9, 219 (1980).

15. T. M. Florence, Analyst [London], 111, 489 (1986).

16. P. Figura and B. McDuffie, Anal. Chem., 51, 120 (1979).

17. M. S. Shuman and M. M. Goldberg, in "Water Analysis: Inorganic Species (Part 2)", R. A. Minear and L. H. Keith (eds.), p. 345, Academic Press, Orlando, 1984.

18. T. Ugapo and W. F. Pickering, Talanta, 32, 131 (1985).

19. J. E. Gregor and H. K. J. Powell, Anal. Chim. Acta, 211, 141 (1988).

20. T. M. Florence, Anal. Chim. Acta, 141, 73 (1982).

21. M. Hiraide, T. Miwa, Y. Iwata and H. Kawaguchi, Anal. Sci., 7, 951 (1991).

22. P. Beněs , E. T. Gjessing and E. Steinnes, Water Res., 10, 711 (1976).

23. R. L. Gustafson and J. Paleos, in "Organic Compounds in Aquatic Environments", S. J. Faust and J. V. Hunter (eds.), p. 213, Marcel Dekker, New York, 1971.

24. Y. Sugimura; Y. Suzuki and Y. Miyake, J. Oceanogr. Soc. Jpn., 34, 93 (1978).

25. E. Nakayama, Y. Suzuki, K. Fujiwara and Y. Kitano, Anal. Sci., 5, 129 (1989).

26. D. J. Mackey, Mar. Chem., 11, 169 (1982).

27. D. J. Mackey, J. Chromatogr., 236, 81 (1982).

28. M. Hiraide, Y. Arima and A. Mizuike, Anal. Chim. Acta, 200, 171 (1987).

29. M. Hiraide, S. P. Tillekeratne, K. Otsuka and A. Mizuike, Anal. Chim. Acta, 172, 215 (1985).

30. M. Hiraide, M. Ishii and A. Mizuike, Anal. Sci., 4, 605 (1988). 
31. S. P. Tillekeratne, T. Miwa and A. Mizuike, Mikrochim. Acta [Wien], 1985 III, 289.

32. H. Yamazaki, S. Gohda and Y. Nishikawa, J. Oceanogr. Soc. Jpn., 35, 233 (1980).

33. M. Hiraide and A. Mizuike, Fresenius' Z. Anal. Chem., 335, 924 (1989).

34. M. Taga, S. Tanaka and M. Fukushima, Anal. Sci., 5, 597 (1989).

35. M. Hiraide, H. Hommi and H. Kawaguchi, Anal. Sci., 6, 479 (1990).

36. M. Hiraide, T. Ueda and A. Mizuike, Anal. Chim. Acta, 227, 421 (1989).

37. D. P. H. Laxen and I. M. Chandler, Anal. Chem., 54, 1350 (1982).

38. T. Nomizu, T. Nozue and A. Mizuike, Mikrochim. Acta [Wien], 1987 II, 99.

39. M. Hiraide, Y. Arima and A. Mizuike, Mikrochim. Acta [Wien], 1988 III, 231.

40. N. Shinozuka, M. Hasegawa, S. Yoshida and S. Hayano, Anal. Sci., 3, 241 (1987).

41. K. L. Cheng, Mikrochim. Acta [Wien], 1977 II, 389.

42. C. J. Miles, J. R. Tuschall and P. L. Brezonik, Anal. Chem., 55, 410 (1983).

43. T. Nomizu, M. Sanji, M. Hiraide and A. Mizuike, Anal. Sci., 5, 363 (1989).
44. R. F. C. Mantoura and J. P. Riley, Anal. Chim. Acta, 76, 97 (1975).

45. J. A. Leenheer, in “Water Analysis: Organic Species", R. A. Minear and L. H. Keith (eds.), p. 83, Academic Press, Orlando, 1984.

46. E. M. Thurman and R. L. Malcolm, Environ. Sci. Technol., 15, 463 (1981).

47. J. I. Kim, G. Buckau, G. H. Li, H. Duschner and N. Psarros, Fresenius' J. Anal. Chem., 338, 245 (1990).

48. M. J. Gomez, I. Marti and L. Donoso, Fresenius'J. Anal. Chem., 339, 664 (1991).

49. M. Hiraide, F. L. Ren and A. Mizuike, Bunseki Kagaku, 36, 219 (1987).

50. M. Hiraide, F. L. Ren, R. Tamura and A. Mizuike, Mikrochim. Acta [Wien], 1987 II, 137.

51. M. Hiraide, H. Kawaguchi and A. Mizuike, Proceedings of 6th Russian-Japan Joint Symposium on Analytical Chemistry, Moscow, Saint-Petersburg, June 1992.

(Received April 22, 1992)

(Accepted June 6, 1992) 